\title{
\#USAS
}

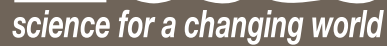

\section{Lahar Hazard Zones for Eruption-Generated Lahars in the Lassen Volcanic Center, California}

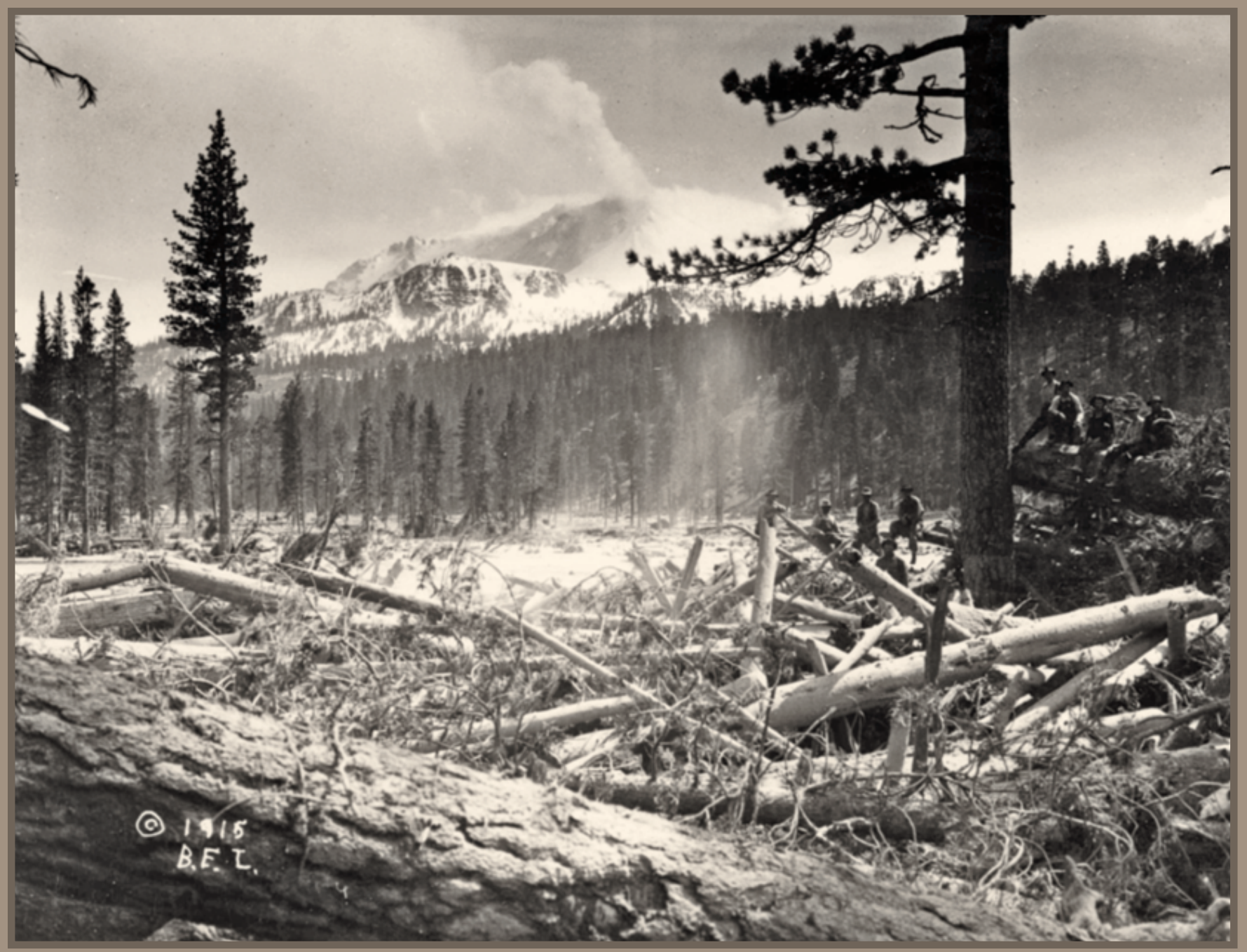

Scientific Investigations Report 2012-5176-C

U.S. Department of the Interior

U.S. Geological Survey 
Cover:

An historic photograph of a logjam in Lost Creek after the lahar of May 19, 1915, at Lassen Peak, taken in 1915 by Benjamin Franklin Loomis, courtesy of the National Park Service. 


\section{Lahar Hazard Zones for Eruption-Generated Lahars in the Lassen Volcanic Center, California}

By Joel E. Robinson and Michael A. Clynne

Scientific Investigations Report 2012-5176-C 


\section{U.S. Department of the Interior \\ KEN SALAZAR, Secretary \\ U.S. Geological Survey \\ Marcia K. McNutt, Director}

U.S. Geological Survey, Reston, Virginia: 2012

For product and ordering information:

World Wide Web: http://www.usgs.gov/pubprod

Telephone: 1-888-ASK-USGS

For more information on the USGS - the Federal source for science about the Earth,

its natural and living resources, natural hazards, and the environment:

World Wide Web: http://www.usgs.gov

Telephone: 1-888-ASK-USGS

This report and any updates to it are available online at: http://pubs.usgs.gov/sir/2012/5176/c/

Any use of trade, product, or firm names is for descriptive purposes only and does not imply endorsement by the U.S. Government.

Although this report is in the public domain, permission must be secured from the individual copyright owners to reproduce any copyrighted material contained within this report.

Suggested citation:

Robinson, J.E., Clynne, M.A., 2012, Lahar hazard zones for eruption-generated lahars in the Lassen Volcanic Center, California: U.S. Geological Survey Scientific Investigations Report 2012-5176-C, 13 p. 


\section{Contents}

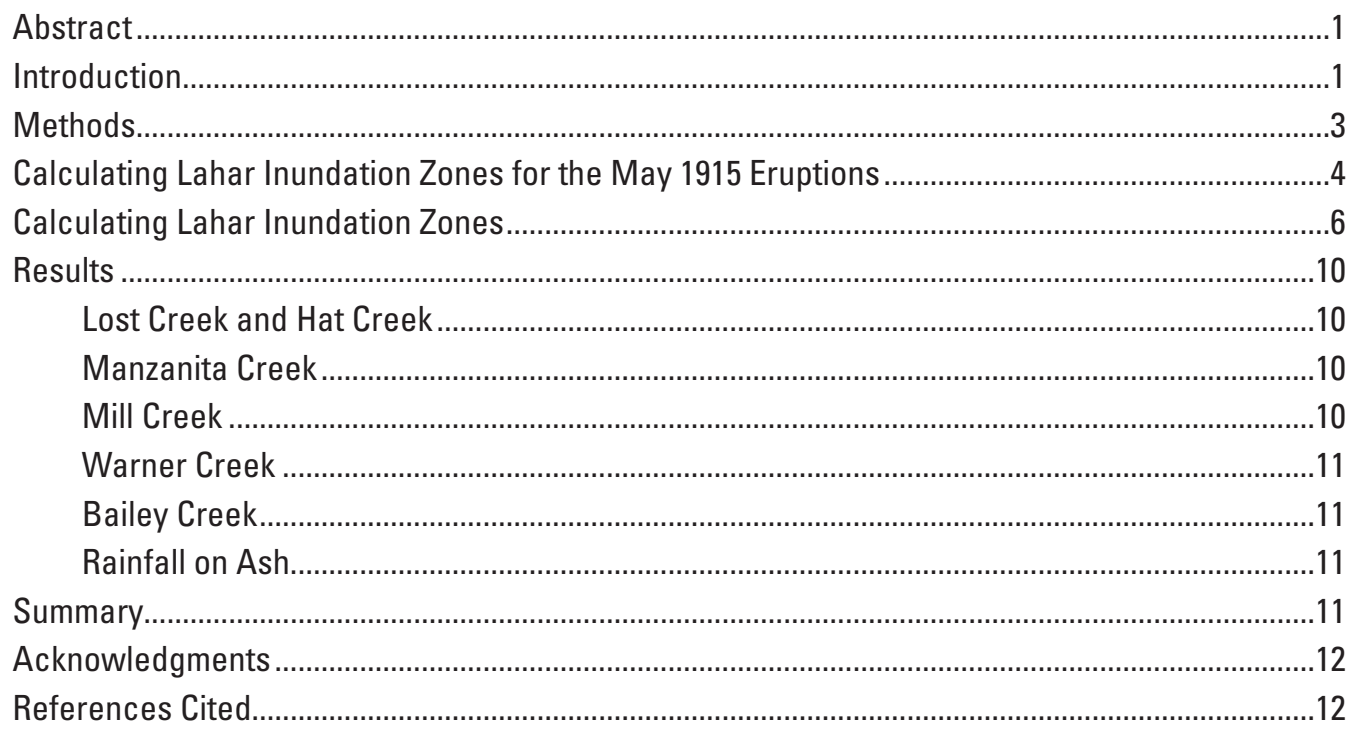

\section{Figures}

1. Map of the Lassen Peak area in northern California in the southern Cascades showing local communities, major roads, and important geographic locations ......................................2

2. Diagram of a generalized lahar path showing geometric relationships between $H$ and $L$ (the height of the edifice, $H$, down to the approximate break in slope at its base, $L$ ) and the cross-sectional and planimetric areas used to delineate each lahar inundation zone ...3

3. Map showing the distribution of lahar deposits from the May 19 and 22, 1915, eruptions of Lassen Peak, California, in pink stipple, and estimated lahar inundation zone, in green, in Lost and Hat Creeks. .4

4. Map of drainage basin areas inside of the potential energy, $H / L$, cone (the height of the edifice, $H$, down to the approximate break in slope at its base, $L$ ) on Lassen Peak, California.

5. Map of lahar inundation zones for drainage basins heading on Lassen Peak, California,

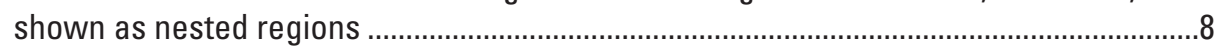

\section{Tables}

1. Areas for parts of basins inside of the potential energy, $H / L$, cone (the height of the edifice, $H$, down to the approximate break in slope at its base, $L$ ) that head on or near Lassen Peak, California, and calculated maximum water and lahar volumes that could be generated. 


\section{Conversion Factors}

\section{SI to Inch/Pound}

\begin{tabular}{lll}
\hline \multicolumn{1}{c}{ Multiply } & By & \multicolumn{1}{c}{ To obtain } \\
\hline & Length & \\
\hline centimeter $(\mathrm{cm})$ & 0.3937 & inch (in.) \\
meter $(\mathrm{m})$ & 3.281 & foot $(\mathrm{ft})$ \\
kilometer $(\mathrm{km})$ & 0.6214 & mile $(\mathrm{mi})$ \\
meter $(\mathrm{m})$ & 1.094 & yard $(\mathrm{yd})$ \\
\hline & Area & \\
\hline square meter $\left(\mathrm{m}^{2}\right)$ & 10.76 & square foot $\left(\mathrm{ft}^{2}\right)$ \\
square kilometer $\left(\mathrm{km}^{2}\right)$ & 0.3861 & square mile $\left(\mathrm{mi}^{2}\right)$ \\
\hline & Volume & \\
\hline cubic meter $\left(\mathrm{m}^{3}\right)$ & 35.31 & cubic foot $\left(\mathrm{ft}^{3}\right)$ \\
cubic meter $\left(\mathrm{m}^{3}\right)$ & 1.308 & cubic yard $\left(\mathrm{yd}^{3}\right)$ \\
cubic kilometer $\left(\mathrm{km}^{3}\right)$ & 0.2399 & cubic mile $\left(\mathrm{mi}^{3}\right)$ \\
\hline
\end{tabular}




\title{
Lahar Hazard Zones for Eruption-Generated Lahars in the Lassen Volcanic Center, California
}

\author{
By Joel E. Robinson and Michael A. Clynne
}

\section{Abstract}

Lahar deposits are found in drainages that head on or near Lassen Peak in northern California, demonstrating that these valleys are susceptible to future lahars. In general, lahars are uncommon in the Lassen region. Lassen Peak's lack of large perennial snowfields and glaciers limits its potential for lahar development, with the winter snowpack being the largest source of water for lahar generation. The most extensive lahar deposits are related to the May 1915 eruption of Lassen Peak, and evidence for pre-1915 lahars is sparse and spatially limited. The May 1915 eruption of Lassen Peak was a small-volume eruption that generated a snow and hot-rock avalanche, a pyroclastic flow, and two large and four smaller lahars. The two large lahars were generated on May 19 and 22 and inundated sections of Lost and Hat Creeks. We use 80 years of snow depth measurements from Lassen Peak to calculate average and maximum liquid water depths, 2.02 meters $(\mathrm{m})$ and $3.90 \mathrm{~m}$ respectively, for the month of May as estimates of the 1915 lahars. These depths are multiplied by the areal extents of the eruptive deposits to calculate a water volume range, $7.05-13.6 \times 10^{6}$ cubic meters $\left(\mathrm{m}^{3}\right)$. We assume the lahars were a $50 / 50$ mix of water and sediment and double the water volumes to provide an estimate of the 1915 lahars, $13.2-19.8 \times 10^{6} \mathrm{~m}^{3}$. We use a representative volume of $15 \times 10^{6} \mathrm{~m}^{3}$ in the software program LAHARZ to calculate cross-sectional and planimetric areas for the 1915 lahars. The resultant lahar inundation zone reasonably portrays both of the May 1915 lahars.

We use this same technique to calculate the potential for future lahars in basins that head on or near Lassen Peak. LAHARZ assumes that the total lahar volume does not change after leaving the potential energy, $H / L$, cone (the height of the edifice, $H$, down to the approximate break in slope at its base, $L)$; therefore, all water available to initiate a lahar is contained inside this cone. Because snow is the primary source of water for lahar generation, we assume that the maximum historical water equivalent, $3.90 \mathrm{~m}$, covers the entire basin area inside the $H / L$ cone. The product of planimetric area of each basin inside the $H / L$ and the maximum historical water equivalent yields the maximum water volume available to generate a lahar. We then double the water volumes to approximate maximum lahar volumes. The maximum lahar volumes and an understanding of the statistical uncertainties inherent to the
LAHARZ calculations guided our selection of six hypothetical volumes, $1,3,10,30,60$, and $90 \times 10^{6} \mathrm{~m}^{3}$, to delineate concentric lahar inundation zones.

The lahar inundation zones extend, in general, tens of kilometers away from Lassen Peak. The small, more-frequent lahar inundation zones $\left(1\right.$ and $\left.3 \times 10^{6} \mathrm{~m}^{3}\right)$ are, on average, $10 \mathrm{~km}$ long. The exceptions are the zones in Warner Creek and Mill Creek, which extend much further. All but one of the small, more-frequent lahar inundation zones reach outside of the Lassen Volcanic National Park boundary, and the zone in Mill Creek extends well past the park boundary. All of the medium, moderately frequent lahar inundation zones $\left(10\right.$ and $\left.30 \times 10^{6} \mathrm{~m}^{3}\right)$ extend past the park boundary and could potentially impact the communities of Viola and Old Station and State Highways 36 and 44, both north and west of Lassen Peak. The approximately $27-\mathrm{km}$-long on average, large, less-frequent lahar inundation zones $\left(60\right.$ and $\left.90 \times 10^{6} \mathrm{~m}^{3}\right)$ represent worst-case lahar scenarios that are unlikely to occur. Flood hazards continue downstream from the toes of the lahars, potentially affecting communities in the Sacramento River Valley.

\section{Introduction}

Lahars, Indonesian for volcanic mudflows or debris-flows, are a rapidly flowing mixture of rock debris and water that originates on the slopes of a volcano. Lahar generation requires an adequate source of water, abundant unconsolidated debris, steep slopes, significant relief, and a triggering mechanism (Vallance, 2000). Various triggering mechanisms include the rapid melting of snow and ice by pyroclastic flows, intense rainfall on loose volcanic rock deposits, a breakout of a lake dammed by volcanic deposits, and a debris avalanche. Unlike many of the other Cascade volcanoes, Lassen Peak in northern California is not a large composite volcano and lacks many of these triggering mechanisms. Lassen Peak, the southernmost active Cascade volcano, is a large volcanic dome, and at 3,187 $\mathrm{m}$ tall (fig.1), it does not reach the high elevations of other composite volcanoes like, for example, Mount Shasta or Mount Rainier. This prevents Lassen Peak from forming the large, perennial snowfields and glaciers that are common at other Cascade volcanoes. Although the flanks of Lassen Peak contain abundant loose debris, the lack of large, perennial snowfields 


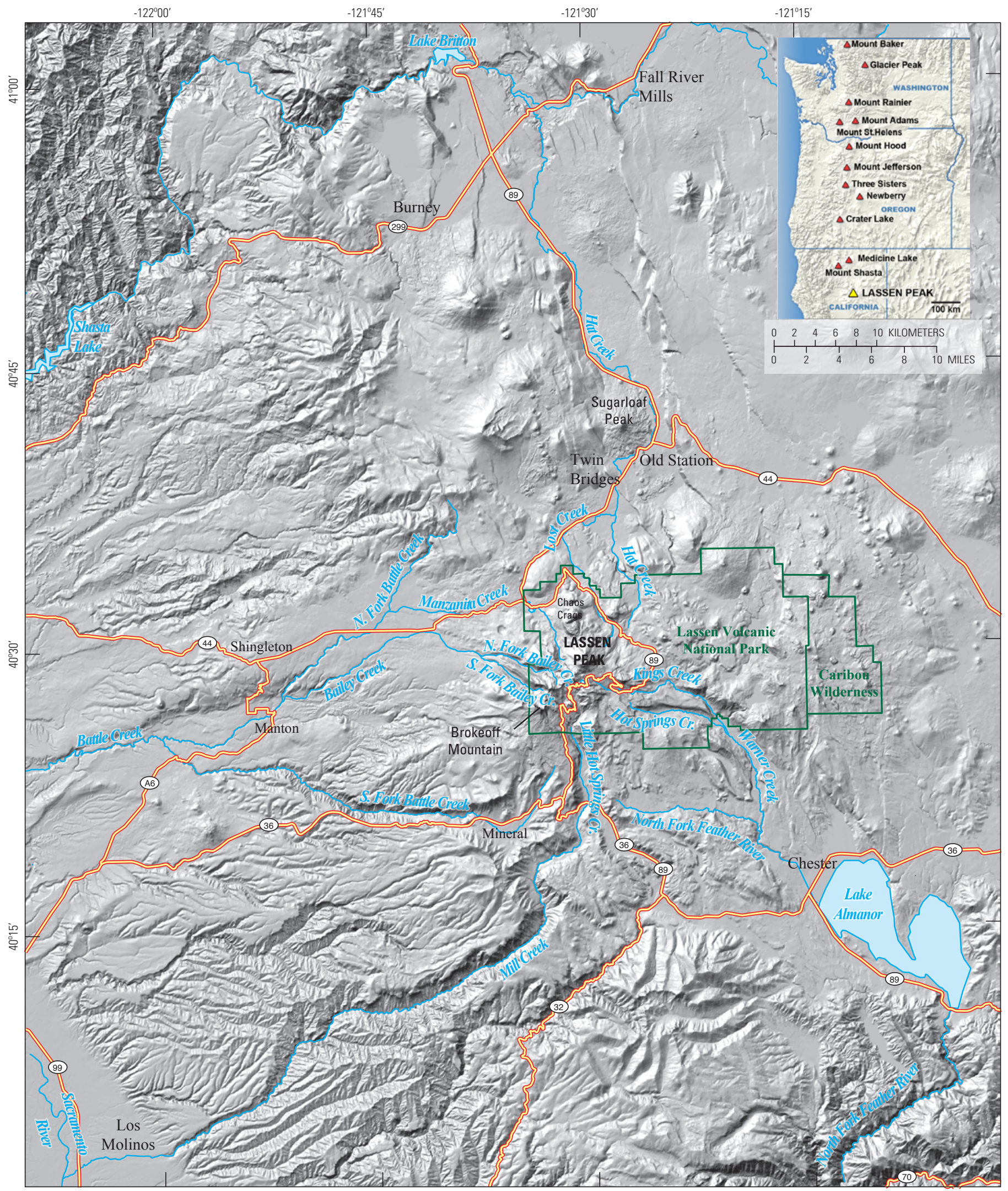

Base from U.S. Geological Survey National Elevation Dataset, Gesch and others, 2002, Gesch, 2007

Figure 1. Map of the Lassen Peak area in northern California in the southern Cascades showing local communities, major roads, and important geographic locations. The Lassen Volcanic National Park and Caribou Wilderness boundaries are a green line. There are 6 major drainages that head on or near Lassen Peak—Lost Creek, Hat Creek, Manzanita Creek, Mill Creek, Warner Creek, and Bailey Creek. 
and glaciers limits the source of water for lahar generation. For this reason, the winter snowpack is the major source of water available to initiate a lahar at Lassen Peak.

In general, lahars are uncommon at Lassen Peak, but lahar deposits are found in drainages that head on or near Lassen Peak (Day and Allen, 1925; Finch, 1930; Williams, 1932; Marron and Laudon, 1987; Eppler and Malin, 1989; Christiansen and others, 2002; Clynne and Muffler, 2010). This demonstrates that valleys heading on Lassen Peak are susceptible to lahars. The most extensive deposits are related to the 1915 eruption of Lassen Peak. During this eruption, two large lahars flowed to the north down Lost Creek to its confluence with Hat Creek, and then continued down Hat Creek (Day and Allen, 1925; Finch, 1930; Williams, 1932; Marron and Laudon, 1987; Eppler and Malin, 1989; Christiansen and others, 2002; Clynne and Muffler, 2010). Dewatering of the lahars caused flooding downstream to just north of Sugarloaf Peak (fig. 1), more than 40 kilometers (km) from the base of Lassen Peak (Willendrup, 1976).

The evidence for pre-1915 lahars is sparse, and the deposits are spatially limited (Marron and Laudon, 1987). The extinct Brokeoff volcano may have been a source for lahars. However, glaciers severely eroded the volcano during the late Wisconsin glaciation (30,000-15,000 years ago) removing it as a potential for future lahars. The glaciation also removed or buried older lahar deposits that may have existed. The Lassen Peak volcanic dome was emplaced approximately 27, 000 years ago during this glaciation (Turrin and others, 1998). There is evidence for mudflows initiated during glacial retreat, but they are very small and confined to the flanks of the dome (Marron and Laudon, 1987; Clynne and Muffler, 2010). There is evidence for one pre-1915 eruption-generated lahar in Manzanita Creek. The emplacement of the Chaos Crags lava domes, approximately 1,050 years ago (Clynne and others,
2008; Clynne and Muffler, 2010), generated a pyroclastic flow that spawned a lahar that nearly reached the intersection of Manzanita Creek and North Fork Battle Creek.

For this study, we estimate present-day susceptibility for lahars initiated from an eruption at Lassen Peak, because the depth of snowpack and the higher elevations than the surrounding region means that the lahar potential is greatest there.

\section{Methods}

We use the LAHARZ software (Schilling, 1998) to estimate lahar potential in creeks that head on or near Lassen Peak. Iverson and others (1998) derived semi-empirical equations from scaling analysis of generic lahar paths and statistical analysis of 27 paths documented at nine volcanoes. They determined that the lahar's volume $(V)$ was proportional to the valley's inundated cross-sectional area $(A)$ and planimetric area $(B)$ through the following equations:

$$
\begin{gathered}
A=0.005 \mathrm{~V}^{2 / 3}, \\
B=200 \mathrm{~V}^{2 / 3} .
\end{gathered}
$$

These equations provide an objective and reproducible method for delineating lahar inundation areas. These equations have an uncertainty factor of two, and they do not take into account physical characteristics of individual flows or varying flow characteristics that may allow flow volumes to inundate more or less than calculated.

These equations are embedded in LAHARZ (Schilling, 1998) and are used to delineate lahar-inundation zones. An important component of the LAHARZ technique is a potential energy, or $H / L$, cone centered at the apex of the volcanic peak (fig. 2). The cone is defined by the height of the edifice $(H)$
Figure 2. Diagram of a generalized lahar path showing geometric relationships between $H$ and $L$ (the height of the edifice, $H$, down to the approximate break in slope at its base, $L$ ) and the cross-sectional and planimetric areas used to delineate each lahar inundation zone. Figure modified from Iverson and others (1998).

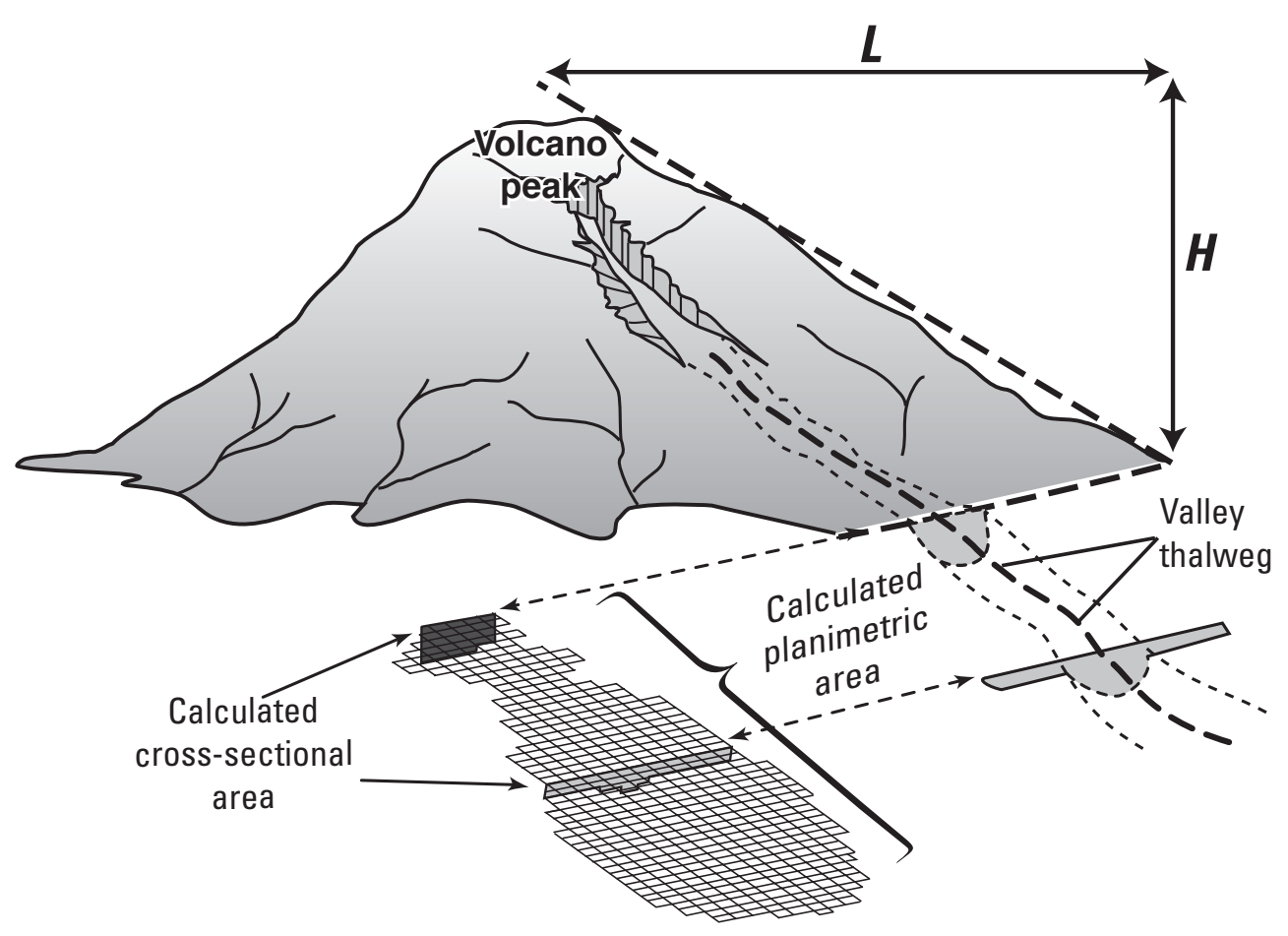


down to the approximate break in slope at its base $(L)$ (Iverson and others, 1998). The intersection between the $H / L$ cone and the Earth's surface marks the initiation point for hypothetical lahars. We choose a $H / L$ cone that intersects the Earth's surface at the base of the volcanic dome that forms Lassen Peak and has a slope of 0.3 (fig. 3). This is within the typical range for cones used in studies of gravitationally driven mass flows, 0.1 to 0.3 (Hayashi and Self, 1992; Iverson and others, 1998).

LAHARZ routes hypothetical lahars down a digital elevation model (DEM) to calculate the cross-sectional and planimetric areas for each given lahar volume. For this study, we use a $1 / 3$ arc-second DEM from the National Elevation Dataset (NED) of the U.S. Geological Survey (USGS) (Gesch and others, 2002; Gesch, 2007). The accuracy of the NED varies spatially depending on the source data. For this study area, the DEM has minimum and maximum elevation values of $97.4 \mathrm{~m}$ and 3,187.0 $\mathrm{m}$, respectively, and the USGS reports a vertical root mean square error of $1.25 \mathrm{~m}$.

\section{Calculating Lahar Inundation Zones for the May 1915 Eruptions}

The May 19 and 22, 1915, eruptions of Lassen Peak were small-volume eruptions generating a snow and hot-rock avalanche, a pyroclastic flow, volcanic ash, and two large and four small lahars. The eruptions are well documented by historical accounts and geologic mapping. We use these descriptions to provide inputs and constraints for LAHARZ to calculate cross-sectional and planimetric areas for the May 1915 lahars. We routed our lahars down present-day topography and assumed that it reasonably represents 1915 channel morphology. The results are then compared with the mapped deposits.

Lassen Peak erupted on May 19, 1915, after a yearlong period of precursory activity. The eruption triggered a snow and hot-rock avalanche down the northeast flank. The avalanche extended to the lower reaches of the Devastated Area (fig. 3), eroding, entraining, and melting the winter snowpack in its path and generating a lahar. Historical accounts (Day and Allen, 1925) describe the quantity of snow on Lassen Peak during the winter of 1914-15 as unusually large, suggesting it was above average. The month of May is when the winter's snow accumulation is typically at its greatest. Pacific Gas and Electric operates a snow gauge on the south flank of Lassen Peak next to Lake Helen (fig. 3) at approximately $2,500 \mathrm{~m}$ elevation. The snow depth and water equivalent depth (snow reduced to its liquid equivalent) were measured 322 times during the months of January-July from 1930-2010. These historical data range from 0.124 to $3.90 \mathrm{~m}$, with a standard deviation of 0.77 , and the average water equivalent depth is $1.63 \mathrm{~m}$. Specifically for the month of May, the data range from 0.350 to $3.90 \mathrm{~m}$ and average $2.02 \mathrm{~m}$. We view the average May water equivalent depth as a conservative estimate for melt water available during the 1915 eruption and the maximum May water equivalent depth as a reasonable upper limit. We use these water depths to estimate the volume of the May 19 and 22 lahars for LAHARZ calculations.

The May 19 avalanche covered an area of $3.49 \times 10^{6}$ square meters $\left(\mathrm{m}^{2}\right)$, outlined by a black dotted line on figure 3 (Christiansen and others, 2002). We use the historical average and maximum water equivalent for May, $2.02 \mathrm{~m}$ and 3.90 $\mathrm{m}$, respectively, as estimates of snowpack encountered by the May 19 avalanche. If the avalanche melted all the snow it encountered, we estimate that between $7.05-13.6 \times 10^{6}$ cubic meters $\left(\mathrm{m}^{3}\right)$ of water was available to initiate a lahar. Christiansen and Clynne (1986) estimated that hot rock in the avalanche had heat content sufficient to melt as much as $14 \times 10^{6} \mathrm{~m}^{3}$ of snow, and we feel it is reasonable for all the snow to be melted even if the maximum amount of snow was present. The avalanche also overtopped Emigrant Pass but only flowed a short way down Hat Creek. The rapid melting of snow and ice by the avalanche initiated a lahar that flowed $16 \mathrm{~km}$ down Lost Creek and stopped near the north end of the andesite lava flows of Raker Peak (Christiansen and others, 2002; Clynne and Muffler, 2010; R.L. Christiansen, oral commun., 2009) (fig. 3). The May 19 lahar deposit covers almost $3.1 \times 10^{6} \mathrm{~m}^{2}$ and has a volume of approximately $6.2 \times 10^{6}$ $\mathrm{m}^{3}$. The combined volume of the melt water and lahar deposit yields a lahar volume of $13.2-19.8 \times 10^{6} \mathrm{~m}^{3}$. As the lahar moved downstream, it mixed with available water becoming more dilute. This muddy flood continued downstream destroying two homesteads approximately $20 \mathrm{~km}$ from the base of Lassen Peak, just north of Twin Bridges. Another 5 $\mathrm{km}$ further downstream near Old Station, it moved a house approximately $15 \mathrm{~m}$ off its foundation depositing more than $0.5 \mathrm{~m}$ of mud inside the house. North of Sugarloaf Peak more than $40 \mathrm{~km}$ downstream from the base of Lassen Peak, the flood was still reported to be flowing in thick, slow waves, and was almost $1 \mathrm{~m}$ above the creek banks (Willendrup, 1976).

Three days later on May 22, the volcano erupted again, producing a pyroclastic flow and lahar. The pyroclastic

Figure 3. Map showing the distribution of lahar deposits from the May 19 and 22, 1915, eruptions of Lassen Peak, California, in pink stipple, and estimated lahar inundation zone, in green, in Lost and Hat Creeks. The pink stippled area delineates the lahar deposits as mapped by Christiansen and others (2002) and Clynne and Muffler (2010). The green area shows lahar inundation from the LAHARZ software (Schilling, 1998) using a volume of $15 \times 10^{6}$ cubic meters $\left(\mathrm{m}^{3}\right)$. The black dotted line shows the extent of the May 19 snow and hot-rock avalanche, and the black dashed line surrounds the limit of the May 22 pyroclastic flow. A red line delineates where a potential energy, $H / L$, cone (the height of the edifice, $H$, down to the approximate break in slope at its base, $L$ ) centered on Lassen Peak with a slope of 0.3 intersects the Earth's surface and is the initiation point for our hypothetical lahars. 


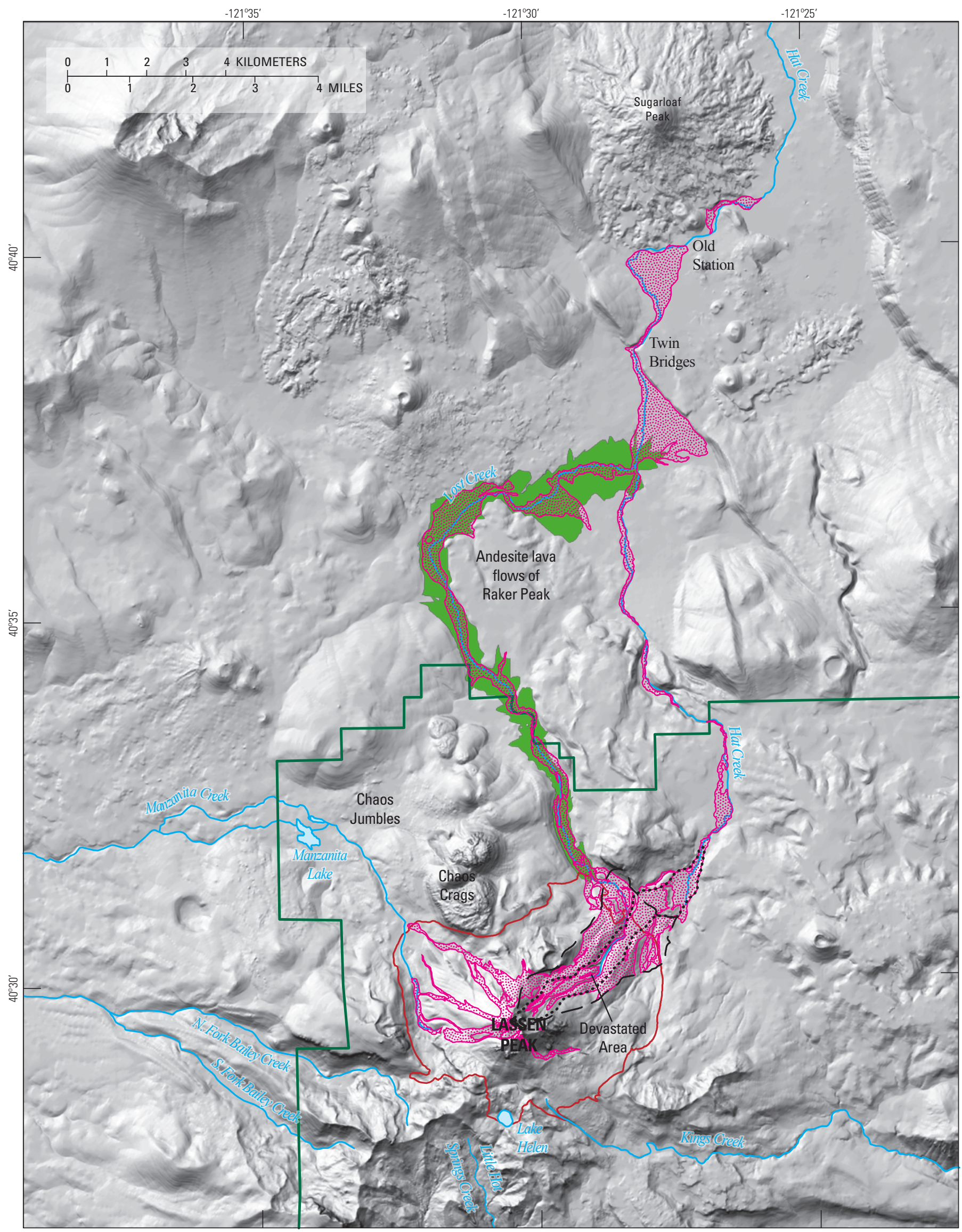

Base from U.S. Geological Survey National Elevation Dataset, Gesch and others, 2002, Gesch, 2007 
flow covered a wider swath of Lassen Peak, outlined by a black dashed line on figure 3, than the May 19 avalanche, covering a total area of $6.81 \times 10^{6} \mathrm{~m}^{2}$. The wider footprint of the pyroclastic flow allowed it to encounter an area of snow, $4.48 \times 10^{6} \mathrm{~m}^{2}$, unaffected by the May 19 avalanche (Eppler and Malin, 1989). We used the same historical average and maximum water equivalent, $2.02 \mathrm{~m}$ and $3.90 \mathrm{~m}$, respectively, as estimates of melt water still available for the May 22 lahar. If the pyroclastic flow melted all of the remaining snow, a volume of water between $9.05-17.5 \times 10^{6} \mathrm{~m}^{3}$ was available to generate the lahar. Again, Christiansen and Clynne (1986) estimated that the pyroclastic flow had heat content sufficient to melt up to $12 \times 10^{6} \mathrm{~m}^{3}$ of snow and ice. The May 22 lahar covered a larger area than the May 19 lahar and was mapped in both Lost and Hat Creeks $22 \mathrm{~km}$ to Old Station (Christiansen and other, 2002). However, the deposit consists of only a thin, sandy sheet containing only sparse, large pumice clasts and dense clasts as much as a few centimeters in size. This suggests that the lahar evolved to a hyperconcentrated flow after passing through the channel constriction at Twin Bridges (R.L. Christiansen, oral commun., 2009). The lahar deposit covers $8.4 \times 10^{6} \mathrm{~m}^{2}$ but is much thinner than the May 19 deposits, with a volume of only $2.1 \times 10^{6} \mathrm{~m}^{3}$. For the May 22 lahar, we combine the melt-water and lahar-deposit volumes to yield a lahar volume range of $11.1-19.6 \times 10^{6} \mathrm{~m}^{3}$. As on May 19, floods continued downstream beyond the extent of the lahar. It was reported that the muddy waters of the floods killed fish throughout the main stem of Hat Creek (Merrill, 1916; Bryant, 1918; California Department of Fish and Game, 1920; U.S. Fish and Wildlife Service, 1998) and suggests that the floods reached as far as $50 \mathrm{~km}$ from Lassen Peak.

We use a volume of $15 \times 10^{6} \mathrm{~m}^{3}$, approximately that of the individual May 1915 lahars, in LAHARZ to calculate a lahar inundation zone. Geologic mapping (pink-stippled polygon on figure 3; Christiansen and others, 2001; Clynne and Muffler, 2010) is overlain on the lahar inundation zone (green polygon on figure 3) in Lost Creek to compare mapped and calculated lahar extents. We choose not to calculate the extents of the upper Hat Creek lahars because they formed when only a small part of the larger avalanche, pyroclastic flow, or lahars overtopped Emigrant Pass, leaving small lahar deposits. There is very little of the May 19 lahar exposed at the surface because the May 22 lahar flowed over and mostly buried it. However, large blocks of dacite of Lassen Peak (a significant component of the May 19 lahar, but not of the May 22 lahar) are found in the subsurface along Lost Creek north of the andesite lava flows of Raker Peak (fig. 3), suggesting that the May 19 lahar extended past these lava flows. The May 22 lahar deposit was mapped in Lost Creek to Old Station. However, considering the nature of the deposits after the constriction at Twin Bridges, we feel that the toe of lahar is closer to Twin Bridges.

The lahar inundation zone (green polygon; fig. 3) ends near the junction of Lost and Hat Creeks. This places the toe of the zone approximately $4 \mathrm{~km}$ past where the May 19 lahar can still be found in the subsurface and only $2 \mathrm{~km}$ from where the May 22 lahar may have evolved into a hyperconcentrated flow. As shown on figure 3, the lahar inundation zone covers a much wider cross section of Lost Creek than is preserved in the deposits. This is not unexpected because generally deposits are thin relative to the depths of initiating flows (for example, Janda and others, 1981) and are not always preserved. We feel that the lahar inundation zone reasonably portrays both the May 19 and 22 lahars, considering the ambiguity of the cessation point of the May 19 lahar, the possible transition of the May 22 lahar to a hyperconcentrated flow, the assumptions used to calculate the lahar volume, and the factor of two uncertainties of the LAHARZ method.

\section{Calculating Lahar Inundation Zones}

We use LAHARZ to create lahar inundation zones in six drainage basins that head on or near Lassen Peak and have the greatest potential for lahars-Lost Creek, Hat Creek, Manzanita Creek, Mill Creek, Warner Creek, and Bailey Creek (fig. 1). The size of the individual lahars depends on the nature of the eruption, especially its explosivity, location of erupting vent, size of the affected area, volume of erupted material, and the water volume available to generate a lahar. As any of these factors increase, the potential for large lahars increase in size. At Lassen Peak, the availability of water is the biggest determining factor for size, and the winter snowpack is the largest source of water available for lahar generation. As the depth of snowpack increases, the potential for larger lahars increases. LAHARZ assumes that the total lahar volume is released at the boundary of the $H / L$ cone and that this volume does not change as the flow progresses downstream (Iverson and others, 1998). Therefore, the total lahar volume is contained within the $H / L$ cone. To better understand potential lahar volumes, we calculate the two-dimensional or planimetric area of each drainage basin that falls within our $H / L$ cone (fig. 4; table 1, column 2). Because snow plays such a large role in water availability, we assume that the maximum historical water equivalent, $3.90 \mathrm{~m}$, covers the entire drainage basin. If an eruption melts all available snow, the product of the drainage basin area and the water equivalent yields the maximum water volume available to initiate a lahar (table 1 , column 3 ). We feel that this maximum water volume for a basin gives us a reasonable upper limit on the possible water volume for any one lahar in a particular drainage basin. In general, lahars are 50 percent or more sediment by volume (for example, Coussot and Meunier, 1996; Scott and others, 1995; Vallance, 2000), so we doubled the water volumes to give a maximum lahar volume for each basin (table 1, column 4).

We use the maximum lahar volumes and an understanding of the statistical uncertainties inherent to the LAHARZ calculations to guide our selection of hypothetical volumes for LAHARZ runs in each of the six drainage basins. We choose six hypothetical volumes, 1, 3, 10, 30, 60 and $90 \times 10^{6} \mathrm{~m}^{3}$, to delineate concentric lahar inundation zones 


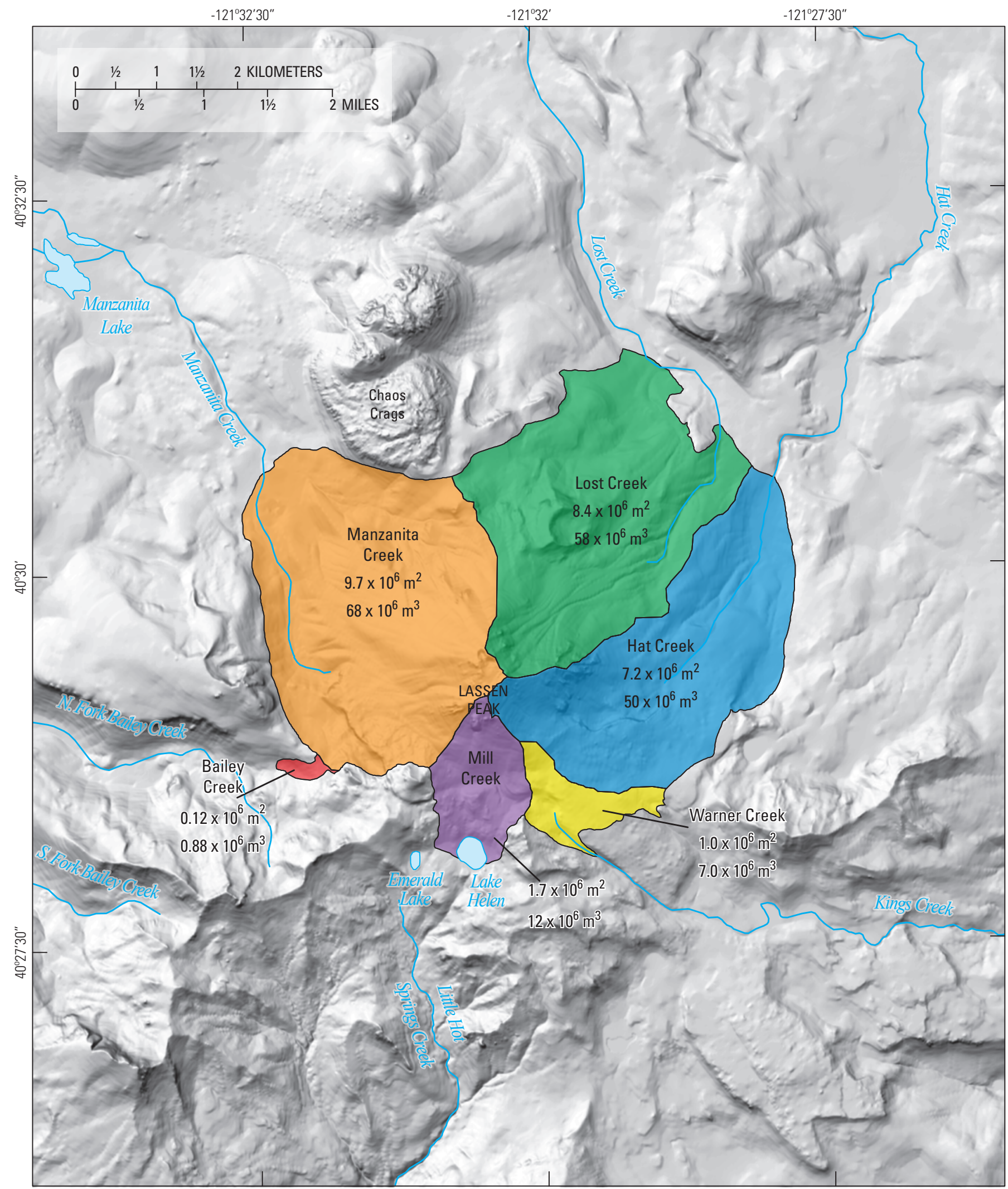

Base from U.S. Geological Survey National Elevation Dataset, Gesch and others, 2002, Gesch, 2007

Figure 4. Map of drainage basin areas inside of the potential energy, $H / L$, cone (the height of the edifice, $H$, down to the approximate break in slope at its base, L) on Lassen Peak, California. Drainage basin areas and maximum lahar volumes are listed for each basin. 
Table 1. Areas for parts of basins inside of the potential energy, $H / L$, cone (the height of the edifice, $H$, down to the approximate break in slope at its base, $L$ ) that head on or near Lassen Peak, California, and calculated maximum water and lahar volumes that could be generated.

$\left[\mathrm{m}^{2}\right.$, square meters; $\mathrm{m}^{3}$, cubic meters $]$

\begin{tabular}{lccc}
\hline & $\begin{array}{c}\text { Drainage basin } \\
\text { area }\end{array}$ & $\begin{array}{c}\text { Maximum water } \\
\text { volume }\end{array}$ & $\begin{array}{c}\text { Maximum lahar } \\
\text { volume }\end{array}$ \\
\hline Lost Creek & $8.4 \times 10^{6} \mathrm{~m}^{2}$ & $29 \times 10^{6} \mathrm{~m}^{3}$ & $58 \times 10^{6} \mathrm{~m}^{3}$ \\
Hat Creek & $7.2 \times 10^{6} \mathrm{~m}^{2}$ & $25 \times 10^{6} \mathrm{~m}^{3}$ & $50 \times 10^{6} \mathrm{~m}^{3}$ \\
Manzanita Creek & $9.7 \times 10^{6} \mathrm{~m}^{2}$ & $34 \times 10^{6} \mathrm{~m}^{3}$ & $68 \times 10^{6} \mathrm{~m}^{3}$ \\
Mill Creek & $1.7 \times 10^{6} \mathrm{~m}^{2}$ & $6.0 \times 10^{6} \mathrm{~m}^{3}$ & $12 \times 10^{6} \mathrm{~m}^{3}$ \\
Warner Creek & $1.0 \times 10^{6} \mathrm{~m}^{2}$ & $3.6 \times 10^{6} \mathrm{~m}^{3}$ & $7.0 \times 10^{6} \mathrm{~m}^{3}$ \\
Bailey Creek & $0.12 \times 10^{6} \mathrm{~m}^{2}$ & $0.44 \times 10^{6} \mathrm{~m}^{3}$ & $0.88 \times 10^{6} \mathrm{~m}^{3}$ \\
\hline
\end{tabular}

(fig. 5). These concentric zones help minimize the statistical uncertainty of the calculations (Iverson and others, 1998). The largest of the proposed lahar volumes, $90 \times 10^{6} \mathrm{~m}^{3}$, is approximately five times larger than either of the May 1915 lahars, and larger than any of the maximum lahar volumes possible for our drainage basins. Although this volume may be unprecedented for the Lassen Region, it encompasses the farthest lahar inundation extent for a $60 \times 10^{6} \mathrm{~m}^{3}$ as suggested by the statistical uncertainties of the LAHARZ method.

In general, lahar and debris-flow magnitude is inversely related to frequency (for example, Scott and others, 1995; van Steijn, 1996; Stoffel, 2010). Typically on large composite volcano, like Mount Rainier, most smaller, more-frequent lahars are glacier or precipitation related, and volcanic eruptions control the frequency of larger lahars. For this study, we consider lahars that are triggered by volcanic eruptions from Lassen Peak. Eruptions in the Lassen region exhibit a similar inverse relationship between magnitude and frequency (Nathenson and others, 2012; Clynne and others, 2012). Therefore, we suggest that lahars originating from Lassen Peak will have a similar relationship. Smaller volume, or magnitude, lahars will occur more frequently, and inundate the smallest areas. Conversely, larger volume, or magnitude, lahars will occur less frequently and will inundate the largest areas. For this report, we will refer qualitatively to areas inundated by lahars of 1 and $3 \times 10^{6} \mathrm{~m}^{3}$ volume as small, more-frequent lahar inundation zones. Similarly, we will refer qualitatively to the areas inundated by lahars of 10 and $30 \times 10^{6} \mathrm{~m}^{3}$ volume as medium, moderately frequent lahar inundation zones, and the 60 and $90 \times 10^{6} \mathrm{~m}^{3}$ volume lahars as large, less-frequent lahar inundation zones. We do not provide any additional quantitative or probabilistic interpretation because LAHARZ does not take into account variations in inundation probabilities from valley to valley, channel slope variations, or instances of hydrothermal alteration (Iverson and others, 1998).

On the figures, lahar inundation zones are shown with sharp boundaries and can appear very irregular when viewed in detail. This jaggedness is an artifact that results from the limited number of cross sections measured by LAHARZ. In reality, these boundaries are not sharp, but gradational and approximately located, and the degree of hazard does not change abruptly at the boundary. Instead, it gradually decreases down the valley away from the volcano and rapidly decreases with increasing elevation above the valley floor (Iverson and others, 1998). Lahars can run up and over small embankments, scour channels, and leave thin deposits when compared to depth of the original flow (for example, Janda and others, 1981). Each of the calculated zones delineates an area of lahar inundation, but not necessarily deposition. Note that potential for flooding downstream still exists as lahars mix with available water and become more dilute (Pierson and Scott, 1985). The lahar inundation zones only provide guidance on the likely range of future lahar inundation, are not forecasts or predictions, and include unprecedented events that are unlikely to occur. We do not know the location of future eruption sites, the nature of the eruptive activity, or the amount of available water in the affected basin. In the event of volcanic unrest, new inundation zones taking into account current knowledge and conditions can be calculated.

Figure 5. Map of lahar inundation zones for drainage basins heading on Lassen Peak, California, shown as nested regions. The zones are rated from small, more-frequent to large, less-frequent lahar inundation, in brick red to green. Each of the six lahar inundation zones were calculated using the LAHARZ software (Schilling, 1998) for hypothetical lahar volumes of 1, 3, 10, 30, 60, and $90 \times 10^{6}$ cubic meters $\left(\mathrm{m}^{3}\right)$. As lahar volume increases, the larger the lahar inundation area becomes and the less frequent the event occurs. Green stretches along creeks delineate areas of potential flooding as lahars become more dilute as they travel downstream (modified from flood hazard zones in Miller, 1989). The potential energy, $H / L$, cone (the height of the edifice, $H$, down to the approximate break in slope at its base, $L$ ) is shown as a red line, and the Lassen Volcanic National Park boundary shown as a green line. See following page. 


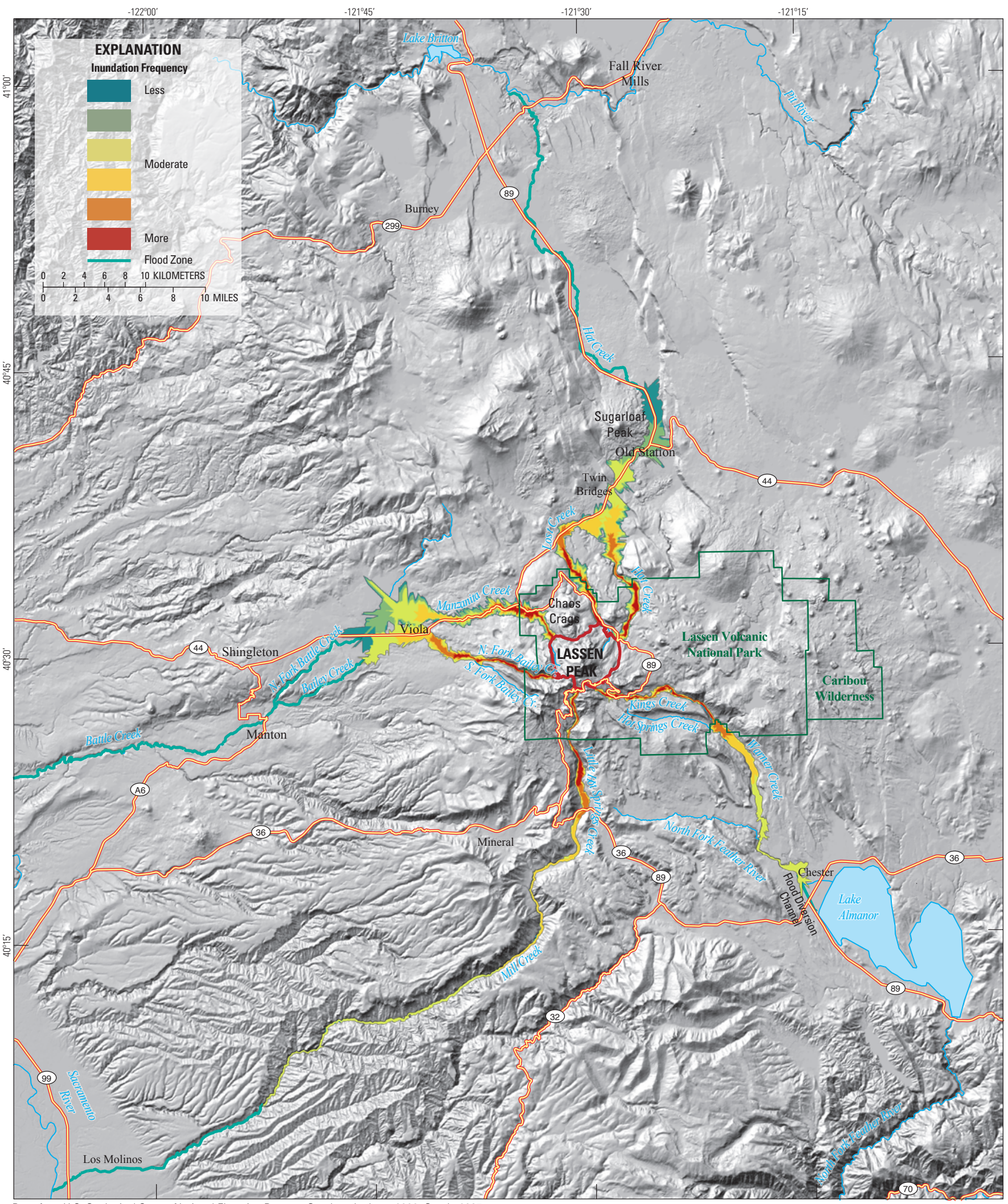

Base from U.S. Geological Survey National Elevation Dataset, Gesch and others, 2002, Gesch, 2007 


\section{Results}

We use the basin sizes to guide our selection of volumes for LAHARZ runs. The three northern basins, Hat Creek, Lost Creek, and Manzanita Creek, are much larger (table 1, column 2) than the three southern basins, and all six hypothetical lahar volumes were used to calculate inundation zones in these basins (fig. 5). The smaller size of the southern basins, Mill Creek, Warner Creek, and Bailey Creek, places limits on possible lahar size, and only the four smaller volumes were used to calculate lahar inundation zones in these basins.

For each basin, we provide a brief overview, and describe the lahar inundation zones. The lahar inundation zones extend, in general, tens of kilometers away from Lassen Peak. The small, more-frequent lahar inundation zones are, on average, $10 \mathrm{~km}$ long. The exceptions are the zones in Warner Creek and Mill Creek, which extend much further. All but one of the small, more-frequent lahar inundation zones reach outside of the Lassen Volcanic National Park boundary, and the zone in Mill Creek extends well past the park boundary. The large, less-frequent lahar inundation zones are, on average, approximately $27 \mathrm{~km}$ long. The communities of Old Station and Viola lie in the zones of medium, moderately frequent lahar inundation (fig. 5). Many more downstream communities, including Chester and Manton, could be at risk from floods associated with larger lahars (green areas in fig. 5).

\section{Lost Creek and Hat Creek}

During the 1915 eruption of Lassen Peak, a hot-rock avalanche and pyroclastic flow descended the northeast section of Lassen Peak creating the Devastated Area (fig. 3 ). These flows removed all vegetation from this area, and deposited abundant unsorted and unconsolidated sediment from silt to cobble in size. Lost and Hat Creeks drain the Devastated Area (fig. 4), with narrow, confined channels that do not broaden significantly for approximately $25 \mathrm{~km}$ downstream. Calculations show that the small, more-frequent lahar inundation zone is almost completely contained inside of the park boundary, however medium, moderately frequent lahars can inundate areas out to Old Station (fig. 5), as was the case with the lahars of May 19 and 22, 1915 (fig. 3). The large, less-frequent lahar inundation zone continues until they pass the junction of State Highways 44 and 89 north of Old Station. As during the 1915 eruptions, there is a possibility of a muddy flood downstream from dilution of the lahar, and flood hazards may continue to the Pit River (Miller, 1989).

\section{Manzanita Creek}

Manzanita Creek has its headwaters on the northwest side of Lassen Peak, and flows to the west, draining the west side of the Chaos Crags lava domes (fig. 5). The Chaos Crags lava domes were emplaced approximately 1,050 years ago, generating a series of pyroclastic flows. One of the pyroclastic flows spawned a lahar that nearly reached the intersection of Manzanita Creek and North Fork Battle Creek. Approximately 725 years later, the Chaos Jumbles (fig. 3), a series of cold-rock avalanches, broke off the Crags and flowed approximately $6 \mathrm{~km}$ to the west damming Manzania Creek to form Manzanita Lake (fig. 5; Clynne and others, 2008; Clynne and Muffler, 2010). The middle reaches of Manzanita Creek contain silt to boulder sized, unsorted, and unconsolidated sediment from the erosion of lava domes, pyroclastic flow deposits, and the Chaos Jumbles. As the creek leaves this section, it encounters Manzanita Lake, which was artificially raised by two feet with an earthen dam in 1913. It has a surface area of close to $0.2 \times 10^{6} \mathrm{~m}^{2}$ and is approximately $1 \times 10^{6} \mathrm{~m}^{3}$ in volume, the same size as our smallest hypothetical lahar volume. The lake is constantly flowing over its spillway, and any material entering the lake will displace the equivalent volume of water potentially causing local flooding. Although the lake may trap small, more-frequent lahars, the medium, moderately frequent and large, less-frequent lahars could incorporate the lake, becoming more fluid, before continuing down stream. Our calculations show that the small, morefrequent lahar inundation zone extends past the Chaos Jumbles and Manzanita Lake (fig. 5). The medium, moderately frequent lahar inundation zone ends in the vicinity of Viola. The large, less-frequent lahars extend past Viola, and across a broad plain before entering the narrow canyon of North Fork of Battle Creek. Flood hazards continue downstream, potentially impacting communities in the Sacramento River Valley (Miller, 1989).

\section{Mill Creek}

East Sulphur Creek begins as springs directly down slope from Lake Helen and Emerald Lake on the south side of Lassen Peak (fig. 4). The creek flows through Little Hot Springs Valley before joining West Sulphur Creek to become Mill Creek. The basin upstream of Lake Helen drains only a small section of Lassen Peak, approximately $1.7 \times 10^{6} \mathrm{~m}^{2}$. The small basin size limits the initiation of large, less-frequent lahars. Therefore, we only calculate inundation zones for the small- to medium-sized hypothetical lahar volumes. Lake Helen, an alpine lake, occupies a cirque on the south side of Lassen Peak at the boundary of the $H / L$ cone. The lake has a surface area of about $0.1 \times 10^{6} \mathrm{~m}^{2}$, and a volume of approximately $2 \times 10^{6} \mathrm{~m}^{3}$. The surrounding closed basin could hold an additional approximately $0.9 \times 10^{6} \mathrm{~m}^{3}$ of material before over topping. The basin may trap the smallest of the hypothetical lahar volumes, but any larger lahar that flows through Lake Helen would incorporate water from the lake, and could become larger. Below Lake Helen, Little Hot Springs Valley is steep, confined and deeply incised, and contains clay-rich, unconsolidated, hydrothermally altered rock, that could be easily eroded and incorporated into lahars. Beyond Little Hot Springs Valley, the valley flattens out as it enters Mill Canyon, and calculations show that the small, more-frequent lahar inundation zone ends here 
(fig. 5). After leaving Mill Canyon, Mill Creek enters a very confined 45-km-long section of Mill Creek that continues to the Sacramento River Valley. The medium, moderately frequent lahar inundation zone ends along this confined section approximately $67 \mathrm{~km}$ from the base of Lassen Peak. Flood hazards continue downstream, potentially impacting communities in the Sacramento River Valley (Miller, 1989).

\section{Warner Creek}

Kings Creek drains a small section, approximately $1.0 \times 10^{6} \mathrm{~m}^{2}$ (fig. 4), on the southeast side of Lassen Peak. It joins with Hot Springs Creek to form Warner Creek, as the two creeks enter Warner Valley. The small-size basin limits the potential for the large, less-frequent lahars. Therefore, we only use the small- to medium-sized hypothetical lahar volumes. The small, more-frequent lahar inundation zone ends before crossing the park boundary near the confluence of Kings Creek and Hot Springs Creek (fig. 5). The medium, moderately frequent lahar inundation zone extends through a broader stretch of Warner Creek and past the junction with North Fork Feather River ending close to the Chester flood diversion channel. The flood diversion channel north of Chester is designed to divert large floods on the North Fork of the Feather River around the town. At design flow, an estimated 3,000 cubic feet per second (cfs) (914 cubic meters per second, $\mathrm{m}^{3} / \mathrm{s}$ ) of water will continue in the North Fork of the Feather River, and approximately 10,000 cfs $(3,048$ $\mathrm{m}^{3} / \mathrm{s}$ ) of water is rerouted into the diversion channel towards Lake Almanor (Central Valley Flood Management Planning Program, 2010, p. 3-17). Flood hazards potentially extend to Lake Almanor (Miller, 1989).

\section{Bailey Creek}

A low drainage divide separates the North Fork of Bailey Creek from Lassen Peak (fig. 4), but a small section of its basin lies inside of Lassen Peak's $H / L$ cone. Any lahar that starts on west side of Lassen Peak would be diverted down Manzanita Creek. However, if a pyroclastic flow or hot rock avalanche were to descend the southwest side of Lassen Peak, it may overtop the divide and generate a lahar in the North Fork of Bailey Creek. The lahar would be limited by the amount of snow melted in this small basin (fig. 4), which has an area of $0.12 \times 10^{6} \mathrm{~m}^{2}$. This limits the potential for large, less-frequent lahars. Therefore, we use only the small- to medium-sized hypothetical lahar volumes. The North Fork of Bailey Creek flows down a steep, narrow canyon and merges with the South Fork of Bailey Creek to form Bailey Creek. Calculations show that the small, more-frequent lahar inundation zone ends just downstream of this junction east of Viola (fig. 5). The medium, moderately frequently lahar inundation zone ends as Bailey Creek reaches the broad plain near Viola. Flood hazards continue downstream, potentially affecting communities in the Sacramento River Valley (Miller, 1989).

\section{Rainfall on Ash}

Although an eruption during winter that entrains and melts snow possesses the largest potential for lahar generation, rainfall on volcanic ash also has the capacity to generate lahars. The National Oceanic and Atmospheric Administration's (NOAA) Western Region Climate Center operates three rain gauges in the Lassen region-Mineral (Station 045679); Chester (Station 041700); and Manzanita Lake (Station 045311). All three gauges have operated at least 60 years. The average monthly rainfall for all three gauges is 8.81 centimeters $(\mathrm{cm})$, and on average, only 11 days a year exceed $2.54 \mathrm{~cm}$ of rain. The worst-case scenario would be an intense 1-day event. The maximum recorded 1-day events for each of the gauges are $15.0 \mathrm{~cm}, 15.0 \mathrm{~cm}$, and $25.48 \mathrm{~cm}$ for Chester, Manzanita Lake, and Mineral, respectively. The events at Chester and Manzanita Lake are approximately double the monthly rainfall average, and the Mineral event is more than 3 times higher. If the maximum 1-day event were to occur on volcanic ash, and the entire volume of rain and ash were available to generate a lahar, then there is the potential for small, more-frequent lahars to occur in the smaller southern drainage basins. In the larger northern drainage basins, there is the potential for medium, moderately frequent lahars to occur.

\section{Summary}

Lahar deposits are found in drainages that head on or near Lassen Peak, demonstrating that these valleys are susceptible to future lahars. However, Lassen Peak's lack of large perennial snowfields and glaciers limits its potential for lahar development, and the winter snowpack is the largest source of water for lahar generation. In general, lahars are unusual at Lassen Peak. Evidence for pre-1915 lahars is sparse and spatially limited, with only one recognized eruption-generated lahar from Chaos Crags. The May 1915 eruption of Lassen Peak was a small-volume eruption that generated a snow and hot-rock avalanche, a pyroclastic flow, and two large and four smaller lahars. The two large lahars were generated when the hot-rock avalanche on May 19 and pyroclastic flow on May 22 rapidly melted the winter snowpack and mixed with easily mobilized sediments. Deposits from these lahars are found in Lost and Hat Creeks.

We use the LAHARZ application and knowledge of snow conditions to calculate lahar inundation zones. Snow depth measurements from a snow gauge by Lake Helen provide an average and maximum (2.02 $\mathrm{m}$ and $3.90 \mathrm{~m}$, respectively) depth of water available for lahar initiation during the month of May. These values along with areal extent of the hot-rock avalanche and pyroclastic flow deposits allow a representative lahar volume for the May 19 and 22 lahars of $15 \times 10^{6} \mathrm{~m}^{3}$ to be estimated. We use this volume in LAHARZ to calculate cross-sectional and planimetric areas for the 1915 lahars. 
The resultant lahar inundation zone reasonably portrays both the May 19 and 22 lahars, considering that May 19 lahar is buried, the nature of the distal May 22 lahar deposit, the assumptions used to calculate the lahar volumes, and factor of two uncertainty in the LAHARZ calculations.

We use the same technique to calculate the potential for future lahars in each basin that heads on or near Lassen Peak. LAHARZ assumes that the total lahar volume is released at the boundary of the $H / L$ cone and that this volume does not change as the flow progresses downstream. Therefore, all the water available to initiate a lahar is contained inside this cone. Because snow is the primary source of water for lahar generation, we assume that the maximum historical water equivalent, $3.90 \mathrm{~m}$, covers the entire area of the drainage basin inside of the $H / L$ cone, yielding the maximum water volume available to initiate a lahar. We double the water volumes to approximate maximum lahar volumes. This and an understanding of the statistical uncertainties inherent to the LAHARZ calculations guided our selection of six hypothetical volumes, $1,3,10,30,60$, and $90 \times 10^{6} \mathrm{~m}^{3}$, for LAHARZ runs to delineate concentric lahar inundation zones. These concentric zones help minimize the statistical uncertainty of the calculations. Although the largest volume, $90 \times 10^{6} \mathrm{~m}^{3}$, may be unprecedented for the Lassen region, it encompasses the entire potential range of lahar inundation areas suggested by the statistical uncertainties.

The lahar inundation zones extend, in general, tens of kilometers away from Lassen Peak. The small, more-frequent lahar inundation zones $\left(1\right.$ and $\left.3 \times 10^{6} \mathrm{~m}^{3}\right)$ are, on average, 10 $\mathrm{km}$ long. The exceptions are the zones in Warner Creek and Mill Creek, which extend much further. All but one of the small, more-frequent lahar inundation zones reach outside of the Lassen Volcanic National Park boundary, and the zone in Mill Creek extends well past the park boundary. All of the medium, moderately frequent lahar inundation zones (10 and $30 \times 10^{6} \mathrm{~m}^{3}$ ) extend past the park boundary and could potentially impact the communities of Viola and Old Station and State Highways 36 and 44, both north and west of Lassen Peak. The approximately $27-\mathrm{km}$-long on average, large, lessfrequent lahar inundation zones $\left(60\right.$ and $\left.90 \times 10^{6} \mathrm{~m}^{3}\right)$ represent worst-case scenarios and are unlikely to occur. Flood hazards continue downstream, potentially affecting communities in the Sacramento River Valley.

\section{Acknowledgments}

The authors wish to thank Steve Schilling and Julia Griswold who helped us understand and implement the LAHARZ method and Mark Reid and Kevin Schmidt who humored neophyte questions about debris flows. John Ewert and William Scott provided invaluable reviews.

\section{References Cited}

Byrant, W.C., 1918, Discretionary powers and game conservation-why discretionary powers are needed: California Fish and Game, v. 4, no. 3, p. 129-130.

California Department of Fish and Game, 1920, U.S. Forest Service Cooperation-mule deer of the Lassen Forest: California Fish and Game, v. 6, no. 3, p. 134-135.

Central Valley Flood Management Planning Program, 2010, State plan of flood control descriptive document: Central Valley Flood Management Planning Office: Central Valley Flood Management Planning Program, 154 p., accessed August 09, 2012, at http://www.water.ca.gov/cvfmp/docs/ SPFCDescriptiveDocumentNov2010.pdf.

Christiansen, R.L., and Clynne, M.A., 1986, The climactic eruptions of Lassen Peak, California, in May 1915 [abs]: Eos, Transactions, American Geophysical Union, v. 67, no. 44, p. 1247.

Christiansen, R.L., Clynne, M.A., and Muffler, L.J.P., 2002, Geologic map of the Lassen Peak, Chaos Crags, and upper Hat Creek area, California: U.S. Geological Survey Geologic Investigations Series I-2723, scale 1:24,000, $17 \mathrm{p}$. (Also available at http://pubs.usgs.gov/imap/i2723/.)

Clynne, M.A., Christiansen, R.L., Trimble, D.A., and McGeehin, J.P., 2008, Radiocarbon dates from volcanic deposits of the Chaos Crags and Cinder Cone eruptive sequences and other deposits, Lassen Volcanic National Park and vicinity, California: U.S. Geological Survey Open-File Report 02-290, 18 p., accessed July 20, 2012, at http://pubs.usgs. gov/of/2002/of02-290/.

Clynne, M.A., and Muffler, L.J.P., 2010, Geologic map of Lassen Volcanic National Park and vicinity, California: U.S. Geological Survey Scientific Investigations Map SIM-2899, scale 1:50,000. (Also available at http://pubs.usgs.gov/ $\operatorname{sim} / 2899 /$.

Clynne, M.A., Robinson, J.E., Nathenson, Manuel, and Muffler, L.J.P., 2012, Volcano hazards assessment for the Lassen region, northern California: U.S. Geological Survey Scientific Investigations Report 2012-5176-A, 47 p., available at http://pubs.usgs.gov/sir/2012/5176/a/.

Coussot, P., and Meunier, M., 1996, Recognition, classification and mechanical description of debris flows: Earth-Science Reviews, v. 40, p. 209-227.

Day, A.L., and Allen, E.T., 1925, The volcanic activity and hot springs of Lassen Peak: Washington, D.C., Carnegie Institution of Washington Publication 360, $190 \mathrm{p}$. 
Eppler, D.B., and Malin, M.C., 1989, The May 1915 eruptions of Lassen Peak, California, I- Characteristics of events occurring May 19, in Latter, J.H., ed., Volcanic hazardsAssessment and monitoring: International Association of Volcanology and Chemistry of the Earth's Interior Proceedings in Volcanology, v. 1, p. 180-200.

Finch, R.H., 1930, Mudflow eruption of Lassen Volcano: The Volcano Letter, no. 237, p. 1.

Gesch, D.B., 2007, The National Elevation Dataset, in Maune, D., ed., Digital Elevation Model Technologies and Applications: The DEM Users Manual, 2nd Edition: Bethesda, Maryland, American Society for Photogrammetry and Remote Sensing, p. 99-118.

Gesch, D., Oimoen, M., Greenlee, S., Nelson, C., Steuck, M., and Tyler, D., 2002, The National Elevation Dataset: Photogrammetric Engineering and Remote Sensing, v. 68, no. 1 , p. 5-11.

Hayashi, J.N., and Self, S., 1992, A comparison of pyroclastic flow and debris avalanche mobility: Journal of Geophysical Research, v. 97, p. 9063-9071.

Iverson, R,M., Schilling, S.P., and Vallance, J.W., 1998, Objective delineation of areas at risk from inundations by lahars: Geological Society of America Bulletin, v. 110, no. 8, p. $972-984$.

Janda, R.J., Scott, K.M., Nolan, K.M., and Martinson, H.A., 1981, Lahar movement, effects, and deposits, in Lipman, P.W., and Mullineaux, D.R., eds., The 1980 eruptions of Mount St. Helens, Washington: U.S. Geological Survey Professional Paper 1250, p. 461-478.

Marron, D.C., and Laudon, J.A., 1987, Susceptibility to mudflows in the vicinity of Lassen Peak, California: U.S. Geological Survey Water-Supply Paper 2310, p. 97-106.

Merrill, H.G., 1916, U.S. Forest Service co-operation-fish killed by mudflow: California Fish and Game, v. 2, no. 2, p. 111.

Miller, C.D., 1989, Potential hazards from future volcanic eruptions in California: U. S. Geological Survey Bulletin $1847,17 \mathrm{p}$.

Nathenson, Manuel, Clynne, M.A, and Muffler, L.J.P., 2012, Eruption probabilities for the Lassen Volcanic Center and regional volcanism, northern California, and probabilities for large explosive eruptions in the Cascade Range: U.S. Geological Survey Scientific Investigations Report 2012-5176-B, 23 p., available at http://pubs.usgs.gov/sir/2012/5176/b/.

Pierson, T.C., and Scott, K.M., 1985, Downstream dilution of a lahar-Transition from debris flow to hyperconcentrated streamflow: Water Resources Research, v. 21, p. 1511-1524.
Schilling, S.P., 1998, LAHARZ - GIS programs for automated delineation of lahar-hazard zones: U.S. Geological Survey Open-File Report 98-638, 89 p.

Scott, K.M., Vallance, J.W., and Pringle, P.T., 1995, Sedimentology, behavior, and hazards of debris flows at Mount Rainier, Washington: U.S. Geological Survey Professional Paper 1547, $56 \mathrm{p}$.

Stoffel, M., 2010, Magnitude-frequency relationships of debris flows-A case study based on field surveys and tree-ring records: Geomorphology, v. 116, no. 1-2, p. 67-76.

Turrin, B.D., Christiansen, R.L., Clynne, M.A., Champion, D.E., Gerstel, W.J., Muffler, L.J.P., and Trimble, D.A., 1998, Age of Lassen Peak, California, and implications for the ages of late Pleistocene glaciations in the southern Cascade Range: Geological Society of America Bulletin, v. 110, no. 7, p. 931-945.

U.S. Fish and Wildlife Service, 1998, Recovery plan for the Shasta crayfish (Pacifastacus fortis): Portland, Oregon, U.S. Fish and Wildlife Service, 153 p.

Vallance, J.W., 2000, Lahars, in Sigurdsson, Haraldur, ed., Academic Press, San Diego, Encyclopedia of Volcanoes, p. 601-616.

van Steijn, Henk, 1996, Debris-flow magnitude-frequency relationships for mountainous regions of Central and Northwest Europe: Geomorphology, v. 15, no. 3-4, p. 259-273.

Willendrup, A.W., 1976, The Lassen Peak eruptions and their lingering legacy: Chico, Calif., Chico State University, unpub. M.A. thesis, $229 \mathrm{p}$.

Williams, Howell, 1932, Geology of the Lassen Volcanic National Park, California: University of California Department of Geological Sciences Bulletin, v. 21, no. 8, p. 195-385.

Produced in the Menlo Park Publishing Service Center, California Manuscript approved for publication, August 14, 2012 Edited by James W. Hendley II Layout and Design by Jeanne S. DiLeo 
吝
总 